\title{
The Role of Music in Leadership: A Case Study of the Governance of Imo State from 2011-2019
}

\author{
Ebele Veronica Ojukwu \& Chima Albert Abiakwu \\ http://dx.doi./org/10.4314/ujah.v20i3.6
}

\section{Abstract}

It is almost resulting to overemphasis to state that music is as old as man, since it is close to impossible to picture a particular time when nature did not furnish man and his society with music. It is equally safe to opine that ever since the need arose for humanity to exist in society as against isolationism, leadership has been present in various shades and with varying degrees of opposition and acceptance. In all civilizations and societies past and present, there has always been a both covert and overt relationship of interdependency between music and leadership since the duo have a common objective which is to better humanity and make the human society efficient, safe and productive. In line with the facts above, this article unveiled the numerous roles which music has played in leadership and vice versa, using their relationship as seen in the governance of Imo State from 2011-2019 as case study. The method used, involved both personal observations of the author as an active member of this society, analysis of the works of some socio-political commentators, analysis of the activities, associations and alliances forged by some political and economic leaders of this society under study, presentation, interpretation and analysis of some musical tracks which have had swaying effects on the trajectory of leadership and the reactions of the masses to these songs. The study discovered that aside the entertainment function of music in this society, it was a strong determinant factor for the ways by which leaders related with the masses and vice 
versa and was also very instrumental in determining the level of acceptance which the masses conferred on their leaders. The author concluded this study by recommending that political and economic leaders should build on this relationship and partner with musicians to chart a path for functional, efficient and more rewarding humanity.

Keywords: Music, Musician, Leadership, Governance, Imo State

\section{Definition of Concepts}

\section{Music}

Music is virtually whatever any society defines it to be as according to Nettl (2010) "each culture has its own conception of the musical universe." A generally accepted definition of music has proved elusive over the years as lots of scholars have tried to depict its meaning and essence from points of view that are more subjective than objective. However elusive an attempt on universal definition for music may be, that it involves the production and combination of sounds that are arranged to serve purposes, communicate ideas and induce feelings is basic. Fundamental to every attempt at a definition of music are the features of sound, organization and functionality. It is a combination of sonic realities that are arranged in systematic forms and shapes with the goal of creating desired effects. Some say it is a combination of organized sounds which are pleasant to the ear. Different authors and scholars have defined it in many ways. In reference to his own musical aesthetic, Varese in Goldman (1961:133) defined music as "an organized sound." For Chou (1966a), this definition stemmed from Varese's vision of sounds as living matter and musical space as open rather than bounded. Varese thought that "to stubbornly conditioned ears, anything new in music has always been called 
noise" thus he posed the question, "what is music but organized noises?" (Varese and Chou, 1966:18). The feature of 'organization' throws us into a further debate between subjectivity and objectivity as what is seemingly organized to one society may be unorganized to another society. Kozinn (1992) pointed out that John Cage, a $20^{\text {th }}$ century composer, thought that any sound can be music, saying, for example, "There is no noise, only sound." Ancient Greek and Indian Philosophers defined music as tones ordered horizontally as melodies and vertically as harmonies. Such sayings as "the harmony of the universe" and "his word is music to my ears" point to the opinion that music is often ordered and pleasant to listen to.

Abiakwu (2016) further observed that: "Music has been analyzed beyond the obvious sound-based perspective to the functional and utilitarian. Seen from this angle, music becomes a socio-cultural reality which occupies a central position in every human society" (p. 9). It seems very safe to say that music is an art form as well as a cultural activity; in this sense it becomes an extension of man (McLuhan 1964), a human activity which is in itself an avenue, a vehicle and according to Umezinwa (2009), a living force. It is in fact a product of the behavior of human groups, whether formal or informal: it is humanly organized sound (Blacking, 1976).

\section{Imo State}

Imo by alphabetical order is the $16^{\text {th }}$ of the 36 states that make up the Federal Republic of Nigeria. It is located within the South-East geopolitical zone of the federation and Owerri is its capital and arguably too its economic hub. Other prominent towns are Orlu, Oguta, Mbaise and Okigwe.Imo State shares its boundaries to the East withAbia State, River Niger and Delta State to the West, the 
Uga region of Anambra State to the North and Rivers State to the South. The state lies within latitudes $4^{\circ} 45^{\prime} \mathrm{N}$ and $7^{\circ} 15^{\prime} \mathrm{N}$, and longitude $6^{\circ} 50^{\prime} \mathrm{E}$ and $7^{\circ} 25^{\prime} \mathrm{E}$ with an area of around $5,100 \mathrm{sq} \mathrm{km}$.

Imo State was among the seven states created by the late Murtala Muhammad on February 3, 1976. Prior to that date, this geographical area was part of East-Central State. The state is named after the Imo River. Part of the state was split off in 1991 as Abia State, and another part became Ebonyi State. With an estimated population of 4,978,758, the major occupations of the people are Agriculture and Commercial activities. Natural resources like crude oil, natural gas, lead, calcium carbonate, Zinc etc, exist in the state. Palm oil is another major income earner for the state.

\section{Administration}

Imo state like all other states within the time of its creation, was administered by 3 Military governors; Ndubuisi Kanu (19761977), Adekunle Lawal (1977-1978) and Sunday Adenihun (19781979) before the first civilian administration under Dee Sam Onunaka Mbakwe of the defunct NPP. With the Buhari's military regime, the state came under the administration of a further four military governors; Ike Nwachukwu (1984-1985), Allison Madueke (1985-1986), Amadi Ikwechegh (1986-1990) and Anthony Oguguo (1990-1992). The short civilian stint of Chief Evan Enwerem (Jan. 1992- Nov. 1993) under the also defunct NRC was followed by another stint of Military administrations under James Aneke (1993-1996) and Tanko Zubairu (1996-1999). With the current democratic dispensation from 1999, Achike Udenwa of the PDP (1999-2007), Ikedi Ohakim of PPA/PDP (2007-2011) and Rochas Okorocha of APGA/APC (2011-2019) have manned the wheels of governance of Imo state with the 
leadership mantle now falling on Chief Emeka Ihedioha also of the PDP.

This paper will dwell more on the periods from 2011-2019, being a period during which the author was actively involved and participatorily aware of the socio-political affairs within the state and how music and leadership intermingled within the politics of Imo state.

\section{Music and Leadership in History}

If in political leadership man attempts to consciously understand and solve the problems of his social life and organization (Sabine \& Thorson, 1973) and in music, man expresses his innermost desires for a better society, then it is logical to state that there actually exists some relationships between leadership and music in the sense that both of them (in their most fundamental contexts) seek the welfare of man. To further buttress this relationship, Thompson (2016) stated:

The very nature of politics is, like music, rooted in conflict and harmony. The heart of music is the interplay of the physical and the mental, as the compromise between them forms a cohesive whole. Compromise is also at the heart of the political process, trying to find common ground and consensus solutions to problems of society through open communication. Both seek to inspire their targets, and both have made great use of the other to advance their ideas.

The musician has a role as a keeper of public conscience and as a man who has his hands on the social control lever (Okafor, 2005) just as the politician has a duty to public welfare and safety. Both the Musician and the Politician guide the society, 
albeit in different but equally effective ways. In every civilization past and present, there has always been music in politics. Political players have always utilized the medium of music either as status symbols as we shall see in the case of Ancient and Medieval times or as veritable instrument in the propagation of their manifestos as seen in contemporary times. The urge to vivify socio-political sentiments through the instrumentality of music is not a novel idea. Wang (1965) observed that as far back as the Xia Dynasty (2000 BC.), Chinese emperors sent officers of their court to record the songs of masons building the great wall, as a rudimentary opinion poll. The songs of wandering Goliards were the simple but very effective means for the expression of anti-clerical feelings in Europe's Middle Ages. The legendary Anglo-Irish song "Lilliburlero" was so effective in checkmating the activities of James II, (Percy 1775) so much so that it became an anthem and muster element that according to Crump (1968) 'sung James II out of three kingdoms.' Such is the effect of music on politics that Andrew Fletcher, a Scottish Nationalist, wrote "if a man were permitted to make all the ballads, he need not care who should make the laws of a nation" (Omond, 1897).

A peep into the socio-political arrangement of biblical times reveals the close marriage between politics and musical activities. There were court musicians who attended to the Pharoahs of Egypt, and as Dunaway (1987) captured it "ever since the blasts of Joshua's trumpets, political movements have turned to music in the service of their campaigns and causes." Even in Greek Mythology, Apollo was credited as the god of music and among the daughters of Zeus (the Muses), Eutherpe and Terpsichore were referred to as the muses that inspired musicians and poets. Hence there is the consciousness from ancient times that music is associated with power. 


\section{Music and the Socio-Political Setting of Europe from Medieval to Post Romantic Era}

The 1,000 years from AD 450 to AD1450 have been designated 'Middle Age' in European history. During this period, European societies were defined along three very distinct and inter-related social classes; the nobility, peasants and clergy. The influence of the Church was simply over bearing as the church was the sole repertory of knowledge, of education and learning. Most Nobles and peasants were largely illiterate and books were very expensive because they had to be hand copied by monks. Since according to Francis Bacon, 'knowledge is power', it was common to have both nobles and peasants attached to the cassock for direction and guidance. Hence while the king was a symbol of authority, the church was arguably the actual wielder of power. Music was only seen at this period in the church, performed by priests, monks, nuns and boys employed into cathedral choirs. It served worship purposes and filled the faithful with awe.

As anyone would expect, music moved into the courts of the Nobles with the dwindling influence of the church orchestrated by the protestant revolution. This movement was not surprising since the Aristocrats would want to maintain their status and command respect and music was already a veritable instrument for such show of class and awe. Medieval secular music began with the works of French minstrel nobles known as the troubadours (in the south) and trouveres (in the north) during the twelfth and thirteenth centuries; chief among them was Guillaume IX, duke of Aquitane. The works of Guillaume de Machaut (1300-1377) musician and poet, among different royal courts and particularly under John of Bohemia, showed how closely knit music was to politics in medieval Europe. 


\section{Music and Politics in Post Medieval Europe}

In 'the book of the courtier' (1528), Castiglione wrote "I am not pleased with the courtier if he be not also a musician." During this period in European history, every educated person was expected to be trained in music. Music was an important curriculum in the education of the time as it was an integral part of the social fabric and of the universal mind. Recall that one of the greatest of all English poets, William Shakespeare belonged to this era. He wrote in 'The Merchant of Venice' one of the most famous tributes to music "the man that hath no music in himself, nor is not moved with the concord of sweet sounds, is fit for treasons, stratagems and spoils." More musical activities gradually shifted from the church to aristocratic courts. Wherever power dwelt, their music made its home. Kings, Princes and Dukes competed for the finest composers; the nobility often brought their musicians along when travelling from one castle to another (Kamien, 2002). The Elizabethan composer Thomas Morley, recounted his embarrassment of being unable to participate in after-dinner music making after music books were shared. All at table were so dumbfounded and demanded in a rather derogatory way, 'how was he brought up?'The above scenario points to the very fact that by the renaissance, music was among the nobility, a way of life, a status symbol and a test of etiquette.

Orlando de Lassus, who was famed as being kidnapped as a boy three times because of the beauty of his singing voice, worked in the courts of Cosimo I de' Medici, Grand Duke of Tuscany from 1550-1553. By 1556, he was in the court of Albrecht V, Duke of Bavaria and his heir Wilhelm V. In 1571 he was knighted by Pope Gregory XIII and he was invited in 1573 by Charles IX, king of France. Most of the prominent musicians of this era were often wooed with scintillating and mouth watering offers coming from 
Kings and Dukes and princes. William Byrd would not have gotten acquainted with Elizabeth (1558-1603) Queen of England at the Chapel Royal had it not been for his musicianship. Lots of examples abound of the symbiotic relationship that existed between music and politics.

Bach was so glued to the court of the sovereign Augustus, Elector of Saxony and King of Poland, Claudio Monteverdi (15671643) served in the court of Mantua for twenty-one years. Arguably the greatest of English composers, Henry Purcell (16591695) was in the service of the King of England and Antonio Vivaldi (1678-1741) was closer to Emperor Charles VI than was any other minister of the King's court. G.F. Handel (1685-1759) was in the service of Elector Georg Ludwig of Hanover and when he took leave and went to London, he became absorbed in the English royal courts that almost all his life was spent there. He was Queen Anne's favorite. Lots of other examples abound in history of the cozy relationship between music and politics. Although one will say that music only enjoyed the patronage of politics, but when you consider the actions of musicians like Beethoven who planned to name his gigantic Third Symphony (The Eroica) Bonaparte, after Napoleon, but withdrew the thought and tore out the dedication after Napoleon proclaimed himself emperor. This evidence reveals that the musician was not just an entertainer to political players, but also a strong critic of their excesses. Gradually this later function as seen in Beethoven (who influenced lots of composers and musicians after him), was heightened by the romantic spirit of Nationalism. Musicians started to get involved in the projection of their national identities, national anthems were composed, indigenous folk tunes were developed and the musician was increasingly making his voice heard. The growth of the middle class was another feature that helped music gain a stronger hold on 
politics. Since the musician had the attention of the romantic middle class who constituted the larger percentage of the society, he could inform their decisions about political matters. Thus the middle class conveyed the message of music to the corridors of power, making music a vehicle of social re-engineering and dynamism. It's (music) effect was so strong that sometimes, after particular performances, audiences began violent protests and revolts against government. As would be expected, certain performances were banned, and censorship boards instituted to rid all musical performances of insurrectionist materials.

\section{Music in the Politics of Nigerian States}

We have been able to trace the symbiosis that has always existed between music and politics from European history, a symbiosis that is not solely Euro-centric. African civilizations have witnessed this common marriage and inter-play. In the era of African nationalism, music was evidently active in the clamour for self governance. The Apartheid regime in South Africa for example, had to contend with lots of musical compositions demanding equality and ultimately the release of Nelson Madiba Mandela.

In Nigeria, the early years of independence, witnessed different musical messages. From the messages for peaceful coexistence to the warnings of mis-management of the commonwealth, corruption and nepotism, musicians like, Sunny Okosun, Sir Warrior and his Oriental Brothers, Fela Anikulapo Kuti etc were visionaries who had foreseen and fore warned the problems we now face as a nation. Fela's 'Zombie', 'beasts of no nation' etc... were enough to polarize the polity and gather popular shame against the Military dictatorship of his time; a feat he paid dearly for with his freedom. Oriental brothers in their vintage performances of the late ' 70 s and early ' 80 s gave all of us (leaders 
and followers) a task "ochichi obodo anyi mekwanu ya k'odi mma." Lots of other such visionary themes punctuated our sociopolitical sphere at different stages of our evolution as a nation. All of them go to further elucidate that music is in fact a major partner of politics as it gives it direction and responses to it (music) serve as primary opinion poll to well meaning administrations. Consequently, the musician recognizes that he has a role as a social critic, who observes critically the events of the society and creates a song with the objective of social control. Okafor and Okafor (2009) captured this role so well as they observed that:

In many instances, he (the musician) is the true voice of the people for he says what everybody is thinking about. Some regimes are not comfortable with him: and they launch oppressive counter measures using the machinery and apparatus of state. In many instances, the more the authorities try to oppress the musician, the more he acquires the elevated status of martyr for truth. (p.38)

\section{Music in Imo Leadership (2011-2019)}

In more recent times, music and politics have enjoyed a very boisterous relationship in the sense that politicians have continuously sought to improve their fame and wider appeal through the services and overt patronage of famous musicians who command very wide following. We have seendancing Senators, Governors, Ministers and Grade A government officials, performing and acting on different stages. In same way, these musicians from whose fame politicians have gained, have also seen their pockets swollen and their lots bettered. There are new offices created by government to accommodate these performers from the state's coffers directly. It is common to hear of such positions as SAs, PAs and EAs to the President/Governors on entertainment. 
This singular narrative is a further affirmation of the symbiosis we have been tracing and has been very evident in the socio-political milieu of Imo State during this period under review.

\section{1-2015}

Chief Achike Udenwa of the PDP had handed the reins of governance to a largely unknown Ikedi Ohakim in what was a very turbulent period in Imo history. The whole polarized and tensed political ambience had climaxed with the victory of PPA, a very unknown political party within the state. It was not altogether surprising to get the feedback from the masses that the new governor who was seen as having climbed to power from the back door was exuding a body language that smirked of highhandedness. The crux of this administration was the Clean and Green initiative that was geared towards making Imo State especially its capital city Owerri the cleanest city in the federation. But Ohakim's administration did not get a second term and the famous chant "Onye ahu tiri fada ihe" was very key in the inability of the Ohakim administration to secure a second term in office.

With the whole tension that was generated by that song which originated from the accusation (which enjoyed popular concurrence) that the incumbent governor had flogged and detained a catholic priest, the opposition ably led by Owelle Rochas Anayo Okorocha, who was known to be a major philanthropist and a power-broker in 'Abuja' Politics, swerved into action, making lots of friends with the masses and swaying them with his characteristic song "My helper oh! My helper..." Okorocha of the APGA eventually won the election and would man the affairs of the state for a further 8 years (2011-2018), winning his second term bid with a smart political strategy which included deriding the name of his major contender Emeka Ihedioha 
of the PDP who was nicknamed 'Emeka Amadioha' (Amadioha being the name of the Igbo Pagan deity of Thunder)

\section{5-2019}

Having won his second term bid and firmly consolidating his stranglehold on power and the state's machinery, Okorocha started to exude the same body language which had ousted his predecessor and consequently began to lose the friendship of the masses who had seen him as a beacon of hope. His lopsided appointments and glaring nepotism began to jar on the nerves of his political associates who felt short-changed by his parochial inclinations. Chief among all these was the resignation of Uche Ogbuagu, who was his SA on entertainment and who doubled as the chief comedian of the State. He was appointed to this position ab initio due to the effects his musical jingles and comic-patterned criticism of the Ohakim administration had on the masses who always followed his shows like mots to fire.

With his resignation, Uche Ogbuagu became the voice of the masses once again, criticizing Okorocha's administration in Songs and comedy. With the establishment of his My Radio 101.1 FM in August 2016, the stage was set to officially voice and air the anger of the people in songs, social commentaries and sociopolitical discussions wherein people called in to express their anger and vent their frustrations. From that time, other musicians who had theme songs that spoke of the highhandedness of the current administration were welcome.

\section{Bishop Ezeribe and His Abigbo Mbaise Group}

Abigbo is a cultural music dance which is native to the Mbaise area of Imo State, an area which boasts of a densely populated landscape with 3 LGAs and a massive political numerical strength. 
This area which is arguably the largest (by numerical strength) single nation within the state, has had the misfortune of not being able to produce a state governor for Imo State, having produced Commodore Luke Chijiuba Ochulor who was the first military administrator of Delta State (having been appointed in 1991). Abigbo in its nature, serves the social function of derision, and sarcastic didacticism. The songs of Bishop Ezeribe and his Abigbo troupe were very instrumental in thwarting the plans of Okorocha to foist his son-in-law on the state as his successor to the chagrin of his party (now APC), the opposition and the entire masses. The following Abigbo performance by Bishop Ezeribe and his crew would be apt at this point:

Ndi Imo State anyi ga wu ewu?

Imo people are we goats?

Ndi Imo State anyi ga wu ewu?

Imo people are we goats?

Owelle lere Imo State gbunyuo anya

Owelle has decimated Imo State

Ng'ogbuforo anyi ya chowa s'ogo ya gbuko anyi

and he wants his son-in-law to complete our decimation

Ya wuru na nkwa a gan'igba y'agba mmm eeh?

If it is music, is it danceable?

Ya wur'akwa joji'any'a gi mma eh! Aaeeh!

If it is beautiful clothing, we will not wear it!

With musical renditions such as these, the masses naturally tripled their anger against the governor and his would-be successor and made good of that anger at the polls, risking injuries and all 
perceivable dangers yet making sure it was a fait accompli to end the perceived dynastic trend.

\section{Post-Election Musicality}

With the announcement of Rt. Hon. Emeka Ihedioha as the governor-elect, the entire state was thrown into a jubilant frenzy. The feeling was that of an accomplished feat and of expectations. Another spectacular instance of music's role in leadership's function of social stability occurred after the announcement of Rt. Hon. Emeka Ihedioha as the governor-elect. Following the fierce battle that had characterized the entire electioneering period and the obvious rivalries and conflicts of interests, Prince Okunwamama who is arguably the most followed Mbaise performer in recent times, delivered another lecture via his music, which he titled "Anyi enweghikwa onye iro ozo" performed in his usual call and response form. An excerpt of the lyrics reads thus:

\section{Calls}

Anyi emeriele...

Anyi emeriele...

Gi hu nwanne gi, nabata ya ooo

Gi hu onye ok'okpa nabata ya

Gi hu onye aziza nabatakwa

\section{Responses}

Anyi enweghikw'ony'iro ozo Anyi enweghikw'ony'iro ozo Anyi enweghikw'ony'iro ozo Anyi enweghikw'ony'iro ozo Anyi enweghikw'ony'iro ozo

It is common knowledge in our clime that partisan politics divides more than it unites, the above song was a perfect cushion; for it brought to the knowledge of the victor that politics is not a 'winner takes it all' venture. The meaning of the excerpt reads thus: 


\section{Calls}

We have triumphed

We have triumphed

If you see your brethren, welcome him

If you see the bearer of the cock, welcome him

If you see the bearer of the broom, We have no enemy anymore welcome him

Both the cock and broom are symbols of two of the major political parties in the state (APGA and APC respectively) whose candidates lost and whose supporters were heart-broken by the final result. I was opportune to broadcast the music live on Facebook and the number of messages I received from those who needed the video sent to them, showed that the music and its message were relevant to the socio-political realities of the time.

\section{Recommendations and Conclusion}

Music and leadership are human activities which are geared towards the singular goal of better humanity; this at least is their most fundamental interest. History and contemporary instances have revealed the eternal symbiosis which exists between these two extensions of man. Some nations have already keyed into this relationship and have invested so heavily in the relationship that both music and leadership now yield huge benefits for them. In fact countries like the United States, UK, Canada, Japan etc have used music to bolster their economy. Connell \& Gibson 2004 discovered that music-related tourism has become an incredibly large industry constituting approximately $17 \%$ of the $\$ 3.5$ billion 
tourism industry in the United States as of 1999. Seattle's music tourism generated $\$ 487$ million in earnings in 2008 (Keblas 2009). It is time for government to partner with musicians and indeed all artists to chart a new and viable option for diversification and revenue earning. Any joint venture will yield lots of economic benefits; music being a feature of culture and intrinsic ingredient of our humanity naturally attracts young people to it, thereby creating employment for them and wealth for the nation.

Secondly, government has over time embarked on the fight against corruption and mal practices of varying degrees. This battle has performed abysmally below par but can be further boosted by the integration of music. What has taken government decades to communicate and millions of tax payers' money in salaries for policy formulators, teachers and law enforcement agents, can be harmoniously communicated through music and it will become a movement in itself. Spender (1972) could not have captured it any better when he stated that "music is the most powerful of idealist drugs except religion." The accepted modes of life and rules of engagement in the society can be propagated through music and the effect will be in-depth as Lomax (1968) opined that characteristic patterns of cultures are carried through its music. Policies against child labour and trafficking in persons can be propagated to reach every facet of the polity through popular songs, nursery and elementary rhymes to send the message down the consciousness of every member of the society. This is in concord with the philosophy of 'sanatio radice' which seeks to heal every problem from the root. Countries like Singapore, Australia etc have all implemented this model of using music to pass-on the messages and policies of government.

Furthermore, beyond the above recommendations, music is always a rallying point for individuals and members of every 
society and is also an avenue for cross-cultural integrations. Government can partner with both traditional and popular musicians to mark-out effective music-events calendar that will ensure steady platforms for socialization and relaxation among members of the society. This closeness will no doubt bridge the divides caused by political interests and foster real integration and rewarding social associations in the quest to achieve fulfilling humanity wherein all members of the society realize their aspirations through cooperation and linkages with other members of their society.

Music has the power to make all the above happen, all it requires is renewed symbiosis with leadership. The song 'We are the world' was all it took mobilize and send aid to victims of famine and natural disaster in Haiti, from people all over the world. Such feats can still happen in our clime and in Imo State precisely if the right partnerships are made.

\section{Ebele Veronica Ojukwu, PhD}

Department of Music

Nnamdi Azikiwe University, Awka

ev.ojukwu@unizik.edu.ng

$\&$

\section{Chima Albert Abiakwu}

Department of Music

Nnamdi Azikiwe University, Awka

ca.abiakwu@unizik.edu.ng 


\section{References}

Abiakwu, C.A. (2016). Music and Tourism: a case study of the traditional musical ensembles of Mbaise origin. (Unpublished bachelor project). Nnamdi Azikiwe University, Awka, Anambra State, Nigeria.

Blacking, J. (1976). How Musical Is Man? Seattle: University of Washington Press, $2^{\text {nd }}$ ed.; London: Faber and Faber.

Chou, W. (1966). "Open rather than bounded". Perspectives of New Music, Vol. 5, no. 1 (Autumn-Winter): 1-6.

Connell, J., \& Gibson, C. (2004). Vicarious Journeys: Travels in Music. Tourism Geographies, 6(1), 2-25.

Crump, G.M. (ed) (1968). Poems on Affairs of State. Augustan Satirical Verse, 1660-1714. Vol. IV. p.314-321. Yale:

New Haven and London.

Dunaway, D. K. (1987). Music and Politics in the United States. Folk Music Journal, 5(3), pp.268-294.

Goldman, R. F. (1961, January). "Varèse: Ionisation; Density Integrales; Octandre; Hyperprism; Poème Electronique. Instrumentalists, cond. Robert Craft. Columbia MS 6146 (stereo)." Musical Quarterly, 47, no. 1 pp.133-34.

Hague, R. \& Harop, M. (2013). Comparative Government and Politics: An Introduction. Macmillan International Higher Education. pp. 1

Kamien, R. (2002). Music: An Appreciation. New York: McGrawHill.

Keblas, J. (2009, April, 3). Seattle Music Office: Economic Impact Study. Retrieved from City of Seattle website: http://www.cityofseattle.net/music/impactstudy.htm.

Kozinn, A. (1992). “. The New York Times. 13 August 1992. Lomax, A. (1968). Folk Song Style and Culture. Washington DC: American Association for the Advancement of Science. 
McLuhan, M. (1964). Understanding Media. New York: McGrawHill.

Nettl, B. (2010, August, 3rd). Music Education and Ethnomusicology: A (Usually) harmonious relationship. Keynote address presented at the $29^{\text {th }}$ meeting of the International Society for Music Education (ISME) in Beijing, China.

Okafor, R \& Okafor, C. (2009). Music and National Development in Nigeria. Enugu: New Generation.

Okafor, R. C. (2005). Music in Nigerian Society. Enugu: New Generation Books

Omond, G.W.Y. (1897). Fletcher of Saltoun. Edinburgh: Oliphent, Anderson and Ferrier.

Percy, T. (1775) Bishop of Dromore. Reliques of Ancient English Poetry, Vol. 3. London: J. Dodsley.

Sabine, G.H. \& Thorson, T.L. (1973). A History of Political Theory. New York: Holt, Rinehart and Winston Inc.

Spender, S. (1972). 'Poetry and Revolution' in the Thirties and After. New York: Vintage.

Thomson, R. (2016). The Intertwined Relationship between Music And Politics. Published in Liveforlivemusic.com Friday, February 26th, 2016.

Umezinwa, E.C. (2009). Igbo music, freedom and philosophy. Awka Journal of Research in Music and the Arts. (AJRMA) Nnamdi Azikiwe University, Awka. 6,128 136. Varese, E., \& Chou, W. (1966). "The Liberation of Sound". Perspectives of New Music 5, no. 1 (Autumn-Winter): 1119.

Wang, B. (1965). Folksongs as Regulators of Politics. The study of folklore, Alan Dundes (ed). New Jersey: Prentice Hall. p.310. 